\title{
MORPHOLOGICAL EXPRESSION OF IMMUNOSUPPRESSION IN POULTRY
}

\author{
R. HALOUZKA and V. JURAJDA ${ }^{1}$
}

Department of Pathological Morphology and Parasitology, Department of Poultry, Fish, Bee and Game Diseases', University of Veterinary Science, 61242 Brno

Received February 27, 1990

\begin{abstract}
Halouzka R., V. Jurajda: Morphological Expression of Imunosuppression in Poultry. Acta vet. Brno, 60, 1991: 271-276.

Cytolytic changes of lymphoid organs in chickens were examined. The changes were evaluated both qualitatively and quantitatively by immunosuppression ( $\mathrm{Si}$ ) rated 0 to 4 . Suitability and importance of this procedure for pathomorphological diagnosis of poultry diseases was assessed.

Marek's disease virus (MDV) at a dose of $10^{3} \mathrm{PFU}$ in $0.2 \mathrm{ml}$ of inoculum administered i.m. and polychlorinated biphenyls (PCB) at a dose of $50 \mathrm{mg} \cdot \mathrm{kg}^{-1}$ of food mixture $K_{1}$ were employed as immunosuppressive agents. Their separate and simultaneous effects were studied. One-day-old Brown Leghorn chickens were MDV infected $(n=9), 5$ birds were infected and fed the contaminated diet, 5 chickens were only fed the contaminated diet and 10 birds served as controls. At three weeks of age all birds were weighed, sacrificed and necropsied. The bursa of Fabricius and spleen of each bird were weighed and sampled for histopathological examination along with the thymus.

Decreased body mass and relative mass of bursa of Fabricius was found in birds infected and fed the above diet. A synergic effect of the MDV and PCB was observed. The detected changes are interpreted in terms of immunosuppression and their importance discussed.
\end{abstract}

Poultry, lymphoid organs, pathological changes, immunosuppression

Morphological structures of avian immune system have some rather primitive features, e.g. the presence of lymphoid tissue clusters in various parts of the body and the absence of mammalian type lymph nodes. The unique lymphoid organ in birds is the bursa of Fabricius; it is the morphological substrate generating humoral immunity. The avian immune system, like that of mammals and unlike that of the phylogenetically lower animals develops germinal centres in the peripheral lymphoid tissue.

Morphological expression of immune reactions and their impairment are thus related to the specific anatomic arrangement of the avian lymphoid system. Immunosuppression results not only in a decrease in immune response but also in morphological lesions of lymphoid organs. Absence and/or a weak antibody response associated e.g. with "vaccine breaks" effects upon pathological processes and resulting secondary infections serve as few examples of adverse effects of immunosuppression of practical importance in modern poultry flocks. Poultry, too, is often exposed to a variety of unfavourable conditions causing immunosuppression and including not only ubiquitously occurring infectious agents (Payne et al. 1976; Powell 1985; Nakamura et al. 1986; Otaki et al. 1988; Piskač et al. 1989) but also stress-inducing factors (Freeman 1985; Powell and Davison 1986).

The aim of the present work was to point out the observed morphological lesions in the lymphoid organs of chickens interpreted as immunosuppression, suitability of the criteria employed for their evaluation and importance of such criteria for pathological diagnostics in poultry diseases. 


\section{Materials and Methods}

In the study, a total of 29 Brown Leghorn chickens from the Institute of Molecular Genetics of Czechoslovak Academy of Sciences (ÚMG CSAV) were employed. One-day-old birds were weighed, randomly alloted to 4 groups as follows: (1) 9 chickens were merely MDV infected and reared on a noncontaminated diet, (2) 5 birds were MDV infected and reared on a diet contaminated with polychlorinated biphenyls (Delor 103, produced at CHEMKO Strážske, CSFR), (3) 5 birds were only fed the contaminated diet and (4) 10 birds served as intact controls. All groups were reared in wire-floor boxes with food and water available ad libitum.

The health state of the chickens was regularly assessed and their body mass recorded. They were sacrificed at 3 weeks of age, necropsied, their bursae of Fabricius and spleens were weighed and along with the thymi sampled for histopathological examination.

The tissue samples were fixed in neutral $10 \%$ formaline and processed by routine paraffine technique, stained with hematoxyline and eosine.

The lesion severity was scored using the following scale (based on our own previous results see Halouzka and Jurajda $(1985,1986)$ and those of Winterfield et al. (1980), Montgomery et al. (1986) as well as Rivas and Fabricant (1988):

\section{Characteristic morphological lesions}

$\mathrm{Si}$

0 - No morphological lesions

1 - Monocellular necroses of lymphocytes and reticular epithelial cells (RE). Gaps of the inner zone of lobular cortex corresponding to the medullar tissue (Plate III, Fig. 1)

2 - Impaired cellularity of the cortex and medulla in consequence of the cytolytic changes, small clusters of cellular debris, increased numbers of Hassal's corpuscles (Plate III, Fig. 2)

3 - Regression of the lobular cortex, frequent clusters of granulocytes in the medulla, hyperemia, enlargement and increased hyalinization of Hassal's corpuscles (Plate IV, Fig. 3)

4 - Atrophy of lobular cortex, only narrow border of lymphocytes is visible below the thymus capsula. Marked organ shrinking, the medulla contains predominantly RE with sporadic lymphocytes and Hassal's corpuscles (Plate IV, Fig. 4)

0 - No morphological lesions

\section{Bursa of Fabricius}

1 - Monocellular necroses of lymphocytes and RE in follicular germinative centres (GC), decreased numbers of lymphocytes in GC appearing thus optically lighter. Sporadic granulocytes infiltrating interfollicular tissue (Plate V, Fig. 5)

2 - Diffuse necrotic changes of lymphocytes and RE, frequent infiltration by granulocytes in GC and in the follicular cortex, depletion of GC, thickened follicular corticomedullar membrane. The lesions affect about $25 \%$ of bursal follicles. Sporadic edema (Plate V, Fig. 6)

3 - Marked depletion of GC, appearance of syncytial structures formed of RE cells in GC bending of thickened follicular corticomedullar membrane, reduction of cortex density caused by markedly decreased number of cellular elements. In some cases, dystrophic changes of epithelial cells representing the continuation of fold surface epithelium and forming a "tuft" of follicle (FAE cells, Lupetti et al. 1983). Total reduction of follicular size, increased interfollicular fibroproduction. More than $50 \%$ of follicles are affected (Plate VI, Fig. 7)

4 - Severe depletion of follicles, only sporadic lymphocytes and cellular debris are present in follicular GC, the corticomedullar membrane disappears and fibrosis of the interfollicular tissue begins with mild lymphocytic and plasmocytic infiltration. The lesions are associated with marked flattening of bursal plicae and a decrease in the size of the organ. The architecture of bursa disappears and cysts emerge. Nearly all follicles are affected (Plate VI, Fig. 8)

0. - No morphological lesion

Spleen

1 - Massive hyperemia with no loss of lymphoid tissue (Plate VII, Fig. 9)

2 - Reduced cellularity of diffuse lymphoid tissue that envelops the central and penicillar arteries. Sporadic foci of necrotic lymphocytes occur in GC ("nodular lymphatic centres") along with proliferation of RE of the capillary sheaths (Plate VII, Fig. 10) 
3 - Atrophy of lymphoid tissue, predominance of reticular elements (Plate VIII, Fig. 11)

4 - Total atrophy and a decreased relative mass of the organ (Plate VIII, Fig. 12)

Index of immunosuppression (Is) was calculated from the ratio of the sum of immunosuppression lesion severity degrees ( $\mathrm{Si}$ ) in individual chickens per the number of examined birds for the general evaluation of immunosuppression based on the observed morphological lessions of lymphoid organs. The relative mass was determined as follows:

$$
\frac{\text { organ mass }}{\text { total body mass }} \times 100
$$

Significance of the differences was assessed by the Student's t-test using a TNS/Gc computer.

\section{Results}

Health state impairment was observed in chickens of groups 2 and 3 at the end the 3rd week of experiment. Clinical symptoms included somnolence, ruffled and discoloured feathers and retarded growth. Gross changes consisted of differences in the mass of bursa of Fabricius and spleen as shown in Table 1.

Specific MD lymphoproliferative lesions were observed in the gonads and skin of two birds in Group 1 and in the skin of one bird in Group 2.

\section{Discussion}

The physiological development and immunocompetence associated with evolution of specific morphological structures should be considered when lymphoid organs are subject to histopathological examination in order to avoid a subjective human factor involved. Both quantitative and qualitative aspects should be taken into account such as the mass of the organs as related to body mass of the animals (Hodges 1974). The thymic mass was not determined in this study because of difficulties involved in collection from the chickens and individual variability. Decrease in body mass and relative mass of BF in chickens of Group 1 caused by

Table 1

Evaluation of immunosuppression in Brown Leghorn chickens at 3wk of age

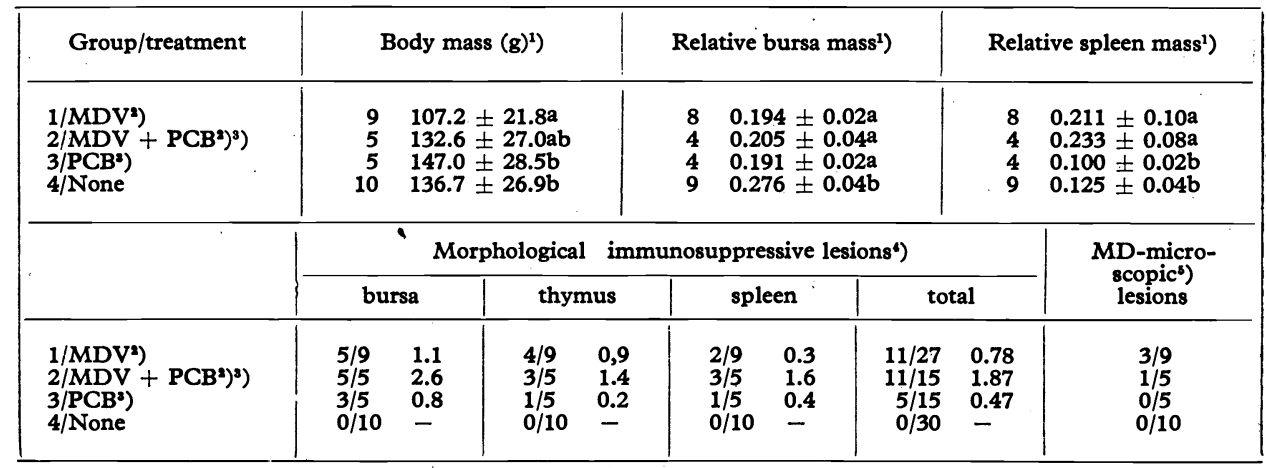

1) No. of birds; mean \pm standard deviation; values with different superscripts are different $(p<0.05)$ by Student t-test

2) One-day chicks infected with $10^{3} \mathrm{PFU} /$ chick intramuscularly in $0.2 \mathrm{ml}$ inoculum

3) Chicken fed the ration $\mathrm{K}-1$ contaminated by DELOR 103 dosed at $50 \mathrm{mg} \cdot \mathrm{kg}^{-1}$ of food

-) Sections positive/sections examined; index

s) Examined: $n$. ischiadicus, plexus brachialis, gonads, skin 
the infectious process and by depletion of germinative centres in bursal follicles were observed in agreement with data of other writers (Pay ne et al. 1976; Calnek and Witter 1984). A significant increase in the spleen mass in this group was attributed mainly to active hyperemia and following proliferation of lymphoid and reticular tissue caused by acute MDV infection. Similar results were obtained in Group 2 except for the absence of statistical significance of the differences in total body mass owing to a small number of experimental birds.

Our results indicate that the scoring system of morphological immunosuppressive lesions proposed in this paper does contribute to the objectivity of pathomorphological examination and thus to more precise interpretation of the findings. It is in agreement with other data on the immunosuppressive character of MDV (Calnek 1986), of PBSs (Safe and Hutzinger 1987) and with quantitative aspects of the evaluation of morphological changes indicative of immunosuppression in MD (Rivas and Fabricant 1988; Winterfield et al. 1980), IBD and reovirus infection (Montgomery et al. 1986) as well. Assessment of Si was only difficult in the spleen (Si 3 and 4) in agreement with Rivas and.Fabricant (1988) due to the anatomical structure and role of this organ in immunopathological processes in birds.

Immunosuppressive agents may act in various phases of cytogenesis of immunocompetent cells and their biochemical processes. Therefore, morphological assesment of immunosuppression is a simplification of diagnosis of tissue damage caused by such complicated events as the immune processes (Bier et al. 1981).

Pathogenesis of immunosuppression is dependent upon sensitivity of the organism, its adaptability, ability to recover and on the character of the causative agent. Evident depletion of thymic lymphocytes and follicular germinative centres of $\mathbf{B F}$ in $M D$ is observed about one week p.i. and the regeneration is related to the resistance of chickens and to virus pathogenity (Pay ne et al. 1976). In IBD, depletion of thymic and BF germinative centres is initiated shortly after infection in sensitive birds (ca 36 hours) with no signs of regeneration and signs of bursa inflammation and lesions in other organs (Naka mura et al. 1986). In CAA infection, depletion of thymus and $\mathrm{BF}$ is not found before day 12 p.i., whereas in frequent $E$. coli infections these lesions can already be found as soon as $12 \mathrm{~h}$ p.i. presumably due to the synergic effect of non-specific stress and toxins. Thymic an I bursal depletion lasts for about 14 days and during this time the chickens are highly susceptible to any other stress or die showing symptoms of septicaemia ( Nakamura et al. 1986). The intensity of cytolytic changes of central lymphoid organs after PCBs administration is directly related to the dose and length of treatment (Halouzka et al. 1990). In this experiment, synergism of MDV infection and low dose of PCBs was shown in chickens of Group 2.

Ubiquitous incidence of the immunosuppressive agents in poultry population can cause immunosuppression if only mild and transient that may lead to disease outbreaks and increased mortality in combination with other immunosuppressively acting factors (stress, environmental contaminants a.o.).

Pathomorphological examination of poultry for possible immunosuppressive lesions of lymphoid organs is easily practicable. The use of quantitative indices may largely contribute to more rapid and correct diagnosis. Along with history data and other examinations immunosuppression can be distinguished as a component of infectious disease from that of different origin. 


\section{Morfologické projevy imunosuprese u drůbeže}

V práci byly vyšetřovány cytolytické změny lymfatických orgánů kư̌at, které byly hodnoceny kvalitativně a kvantitativně stupni imunosuprese $(\mathrm{Si})$ od 0 do 4 a posouzena jejich vhodnost a význam $\mathrm{v}$ patomorfologické diagnostice chorobných stavů drůbeže.

Jako imunosupresivní faktory byly použity virus Markovy nemoci (MDV) $\mathrm{v}$ dávce $10^{3} \mathrm{PFU}$ v $0,2 \mathrm{ml}$ inokula i.m., polychlorované bifenyly $(\mathrm{PCB}) \mathrm{v}$ dávce $50 \mathrm{mg} \cdot \mathrm{kg}^{-1} \mathrm{krmiva} \mathrm{K} 1$ a jejich simultánní působení. Jednodenní kuřata Brown Leghorn byla rozdělena na skupinu 9 infikovaných, 5 infikovaných a krmených kontaminovanou směsí, 5 krmených kontaminovanou směsí a 10 kuřat kontrolních. Kuřata byla zvážena a utracena ve 3. týdnu věku. Bylo provedeno patomorfologické vyšetřeni. Fabriciova burza a slezina byly zváženy a vzorky těchto orgánů a thymu histopatologicky vyšetřeny.

Zjistili jsme snížení tělesné hmotnosti a relativni hmotnosti Fabriciovy burzy u kư̌at infikovaných a krmených kontaminovanou směsí. Prokázali jsme synergický účinek MDV a PCB na intenzitu imunosuprese. Ověřili jsme, že kritéria hodnocení morfologických imunosupresivních změn stupni imunosuprese $\mathbf{v}$ centrálních lymfatických orgánech a slezině přispívají $\mathrm{k}$ objektivnosti patomorfologického vyšetření a přesnější interpretaci změn. Společně s anamnestickými údaji a dalším šetřením mohou pomoci odlišit imunosupresi při různých chorobných stavech.

\section{Морфологические проявления иммүносүпрессии птицы}

В работе проводились исследования морфологических изменений лимфатических органов цыплят, последствия которых толковали в качестве иммуносупрессии. Быявленные иммуносупрессивные изменения оценивали количественно и качественно степенью иммуносупрессии (Si) от 0 до 4 с приведением оценки их пригодности и значения в пагоморфологической диагностике болезненных состояний птицы.

В качестве иммусупрессивных факторов использовали вирус Марека (MDV), полихлорованные дифенилы (РСB) в препарате Delor 103 и их одновременное воздействие. Суточного возраста цыплята Броун Легорн, неинфицированные и инфицированные дозой $10^{3}$ PFU MDV в 0,2 мл инокулята внутримышечно, кормпленные неконтаминированной и контаминированной смесью к 1 дозой $50 \mathrm{Mr} \mathrm{PCB} / \mathrm{kr}$ кормов, взвешизали и үмерщвляли в возрасте 3 недели. Проводили патоморфологические исследования, взвешивали фабрициеву сүмку и селезенку, образцы упомянутых органов и зобной железы гистопатологически исследовали.

Были установлены понижение массы тела и относительная масса фабрициевы сүмки у цыплят, инфицированных и кормленных контамированной смесью. Установили синергеитческое воздействие MDV и PCB на интенсизность иммуносупрессии. Проверили, что критерии оценки морфологических иммуносупрессивных зменений степенью иммуносупрессии в центральных лимфатических органах и селезенке способствуют объективности патоморфологического исследованиз, точнее, интерпретации изменений. Совместно с данными анамнеза и другими исследованиями они могут способствовать различению иммуносупрессии при разных болезненных состояниях. 


\section{References}

BIER, O. G.-DIAS da SILVA, W.-GÖTZE, D.-MOTA, I.: Základy imunologie. Springer-Verlag N. Y. - Heidelberg-Berlin, 1981, překl. Avicenum, Praha, 1984, 422 p

CALNEK, B. W.: Marek's Disease - A Model for Herpesvirus Oncology. CRC Critical Reviews in Microbiology, 12, 1986: 293-320

CALNEK, B. W.-WITTER, R. L.: Marek's disesase. In: Diseases of Poultry, Iowa State University Press, Ames, 1984: 325 p

FREEMAN, B. M.: Stress and domestic fowl: physiological fact or fantasy? Wld's Poult. Sci. J., 41, 1985: 45-51

HALOUZKA, R.-JURAJDA, V.: Morfologické studium imunosupresivního účinku viru MN-kmene GA. In: Proceedings of the Poultry Diseases Conference, Rabyně, 1985: 91

HALOUZKA, R. - JURAJDA, V.: Atypické morfologické změny ve Fabriciově burze kuřat po infekci virem Markovy nemoci. In: Proceedings of the II. Veterinary Oncological Days, Brno, 1986: 47-48

HALOUZKA, R.-RUPRICH, J.-PISKAC, A.: Účinek polychlorovaných bifenylů (PCB) na organismus kuřat: patologické změny orgánů po krátkodobém a dlouhodobém příjmu vysokých dávek Deloru 103. Veter. Med. (Praha), 40, 1990, in press

HODGES, R. D.: The Histology of the Fowl. AP London, 1974: $648 \mathrm{p}$

LUPETTI, M. -DOLFI, A.-MICHELUCCI, S.: The behaviour of Bursal Lymphoid Follicle - Associated Cells after Treatment with Testosterone. The Anatomical Record, 205, 1983: $177-183$

MONTGOMERY, R. D.-VILLEGAS, P.-DAWE, D. L.-BROWN, J.: A comparison between the Effect of an Avian Reovirus and Infections Bursal Disease Virus on Selected Aspects of the Immune System of the Chicken. Avian Dis., 30, 1986: 298-308

NAKAMURA, K.-IMADA, Y.-MAEDA, M.: Lymphocytic Depletion of Bursa of Fabricius and Thymus in Chickens Inoculated with Escherichia coli. Vet. Pathol., 23, 1986: 712-717

OTAKI, Y.-NUNOYA, T.-NAJIMA, N.-KATO, A.-NOMURA, Y.: Depression of vaccinal immunity to Marek's disease by infection with chicken anemia agent. Avian Pathol., 17, 1988: $333-347$

PAYNE, L. N.-FRAZIER, J. A.-POWELL, P. C.: Pathogenesis of Marek's disease. Int. Rev. Exp. Pathol., 16, 1976: 59-153

PISKAČ, A. - RUPRICH, J. - HALOUZKA, R.: ÚCinek polychlorovaných bifenylů na organismus kuřat. Biol. chem. Vet. (Praha), 25, 1989: 418-421

POWELL, P. C.: Host resistance factors: immune responses - a review. In: Internat. Symposium on Marek's disease. Edit. Calnek, B. W. and Spencer, J. L., Ithaca, Amer. Assoc., of Avian Pathologists, 1985: 238-261

POWELL, P. C.-DAVISON, T. F.: Induction of Marek's disease in vaccinated chickens by treatment with betamethasone or corticosterone. Israel J. vet. Med., 42, 1986: 73-78

RIVAS, A. L. -FABRICANT, J.: Indications of immunodepression in chickens infected with various strains of Marek's disease virus. Avian Dis., 32, 1988: 1-8

SAFE, S. - HUTZINGER, O.: Polychlorinated Biphenyls (PCBs): Mammalian and Environmental Toxicology. In: Environmental Toxin Series 1, Springer-Verlag Berlin Heidelberg, 1987: 152

WINTERFIELD, R. W.-DHILLON, A. S.-THACKER, H. L.-ALLY, L. J.: Immune Response of White Leghorn Chicks from Vaccination with Different Strains of Infectious Bursal Disease Virus and in Presence of Maternal Antibodies. Avian Dis., 24, 1989: 179-188 


\section{Plate III.}

Halouzka R. -Jurajda V.: Morphological ... pp. 271-276.

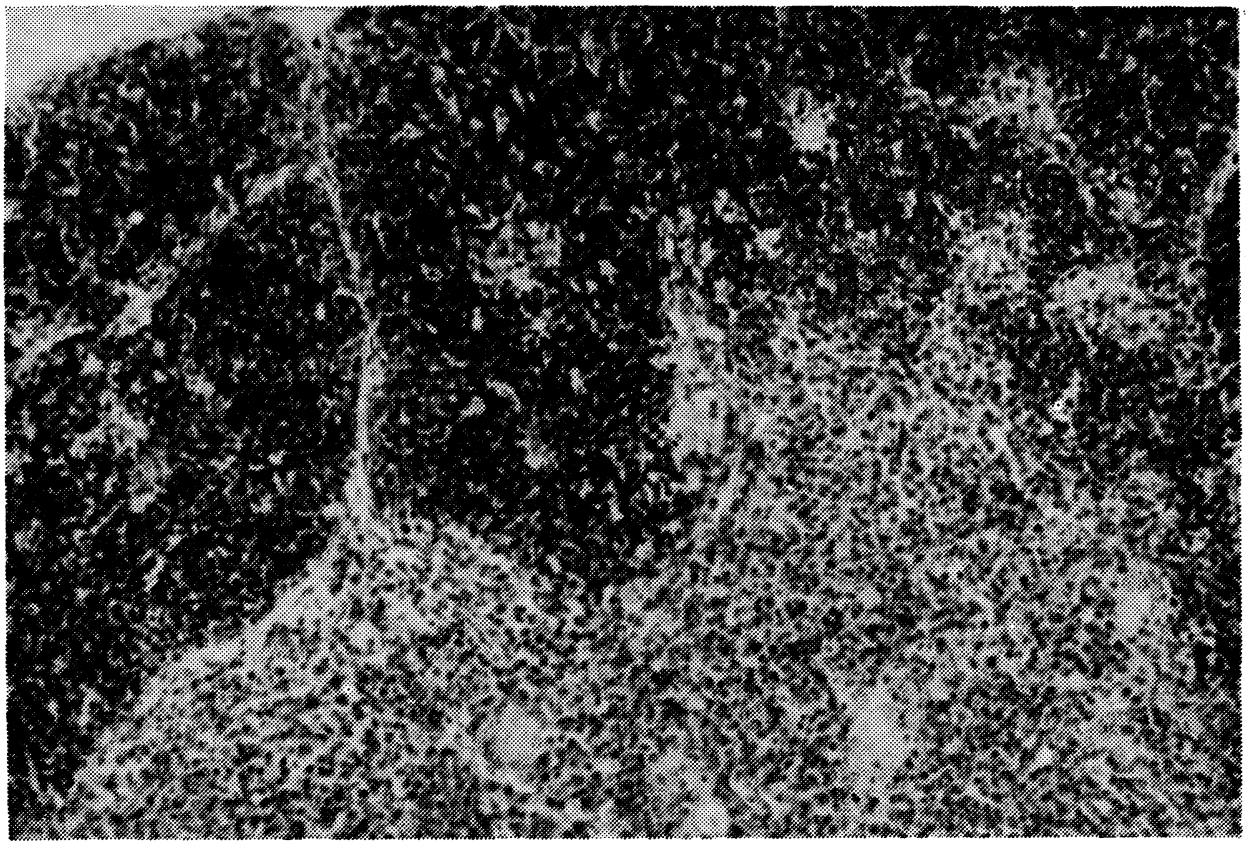

Fig. 1. Thymus, $\mathrm{Si}-1$

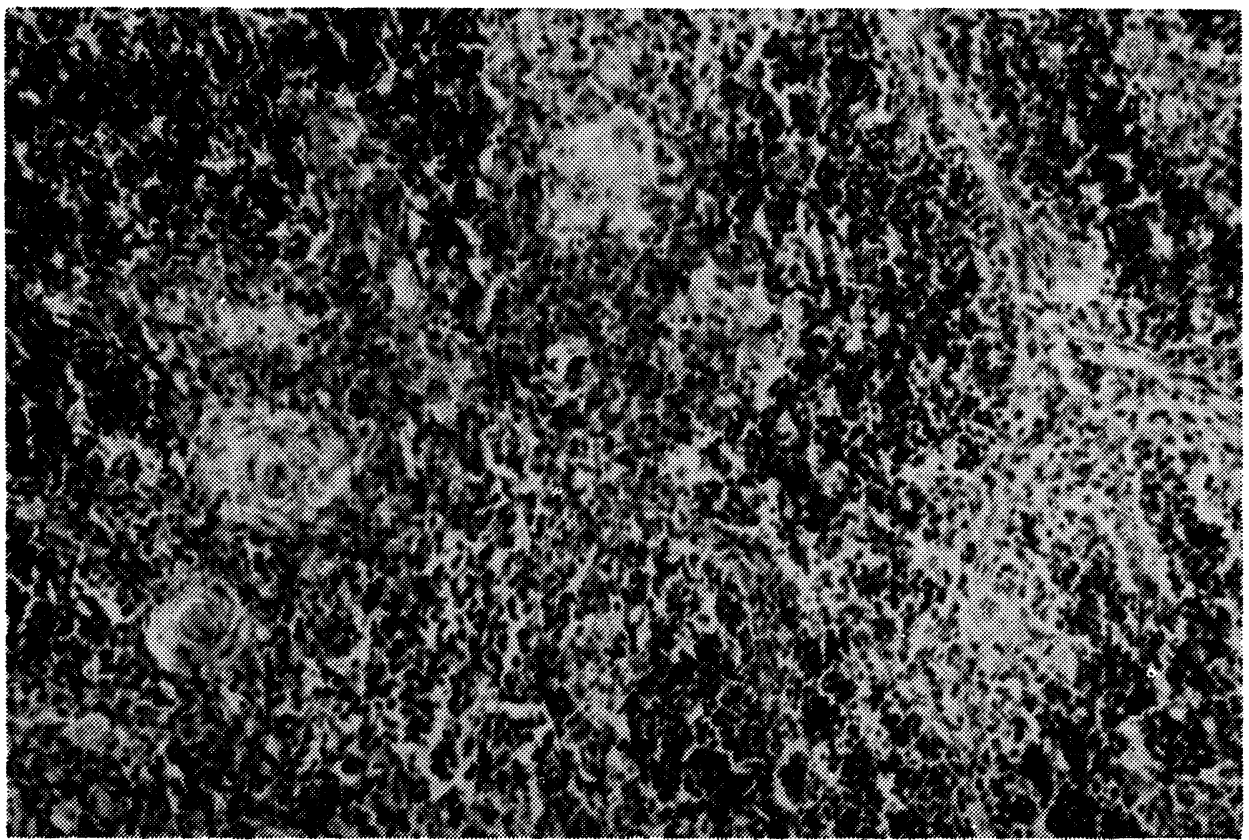

Fig. 2. Thymus, $\mathrm{Si}-2$ 
Plate IV.

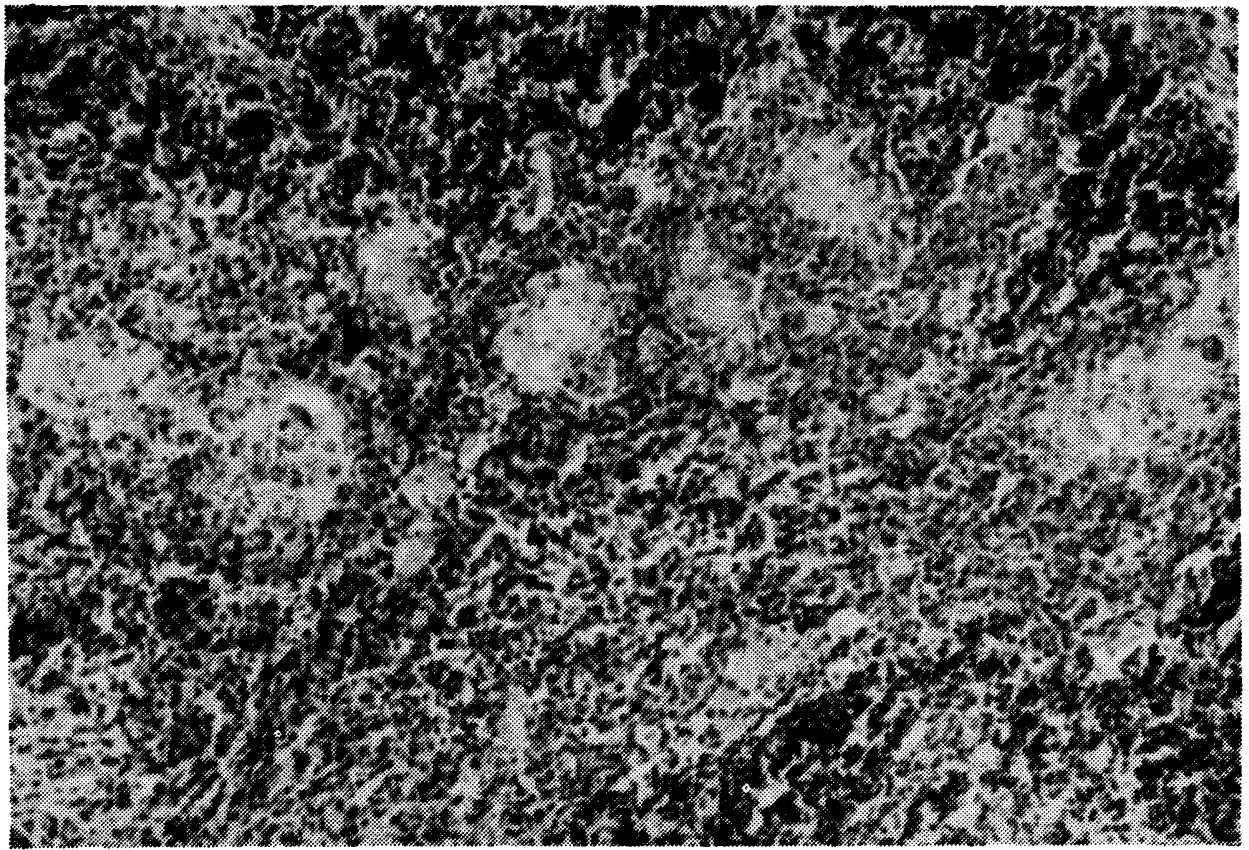

Fig. 3. Thymus, $\mathrm{Si}-3$

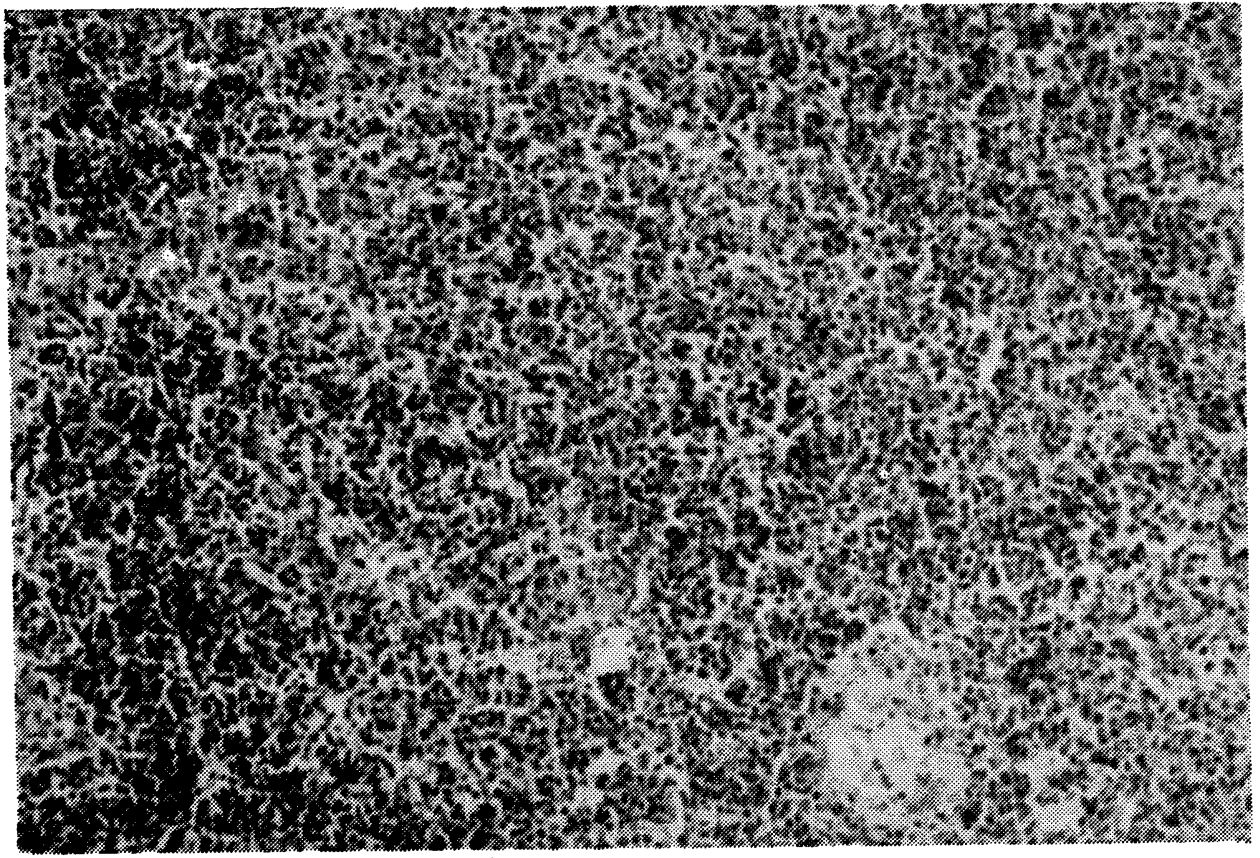

Fig. 4. Thymus, $\mathrm{Si}-4$ 


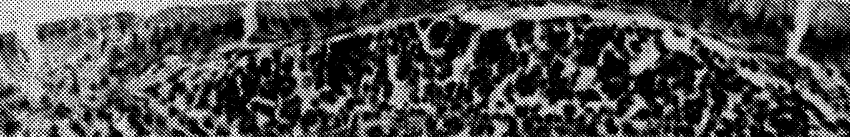

OP 2820 .

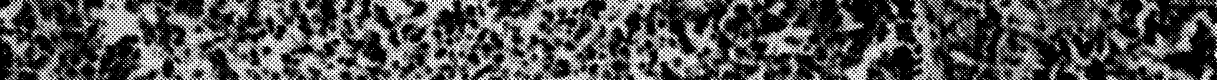

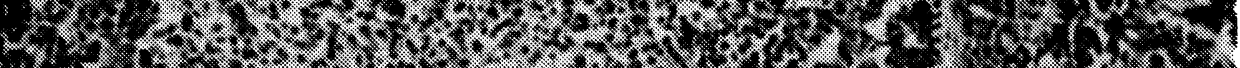

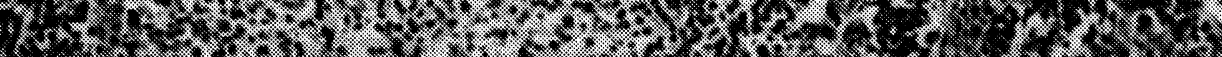
f

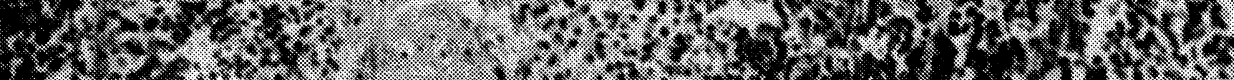

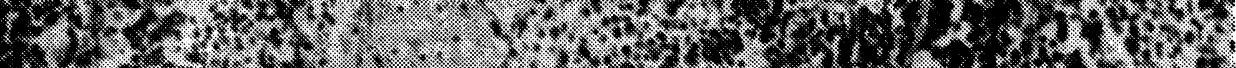
F

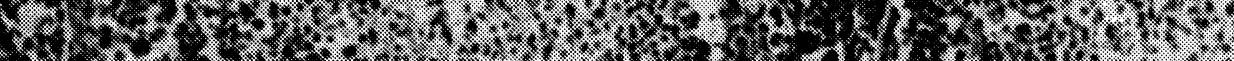

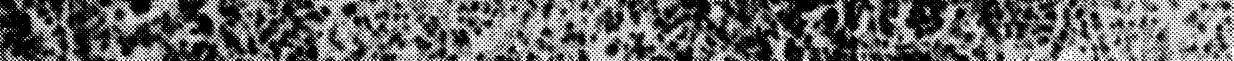
7.

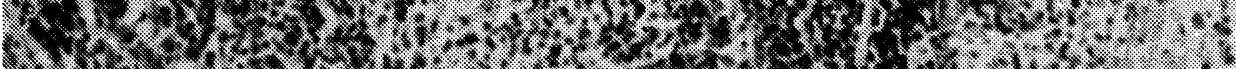

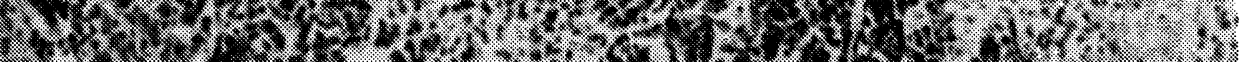

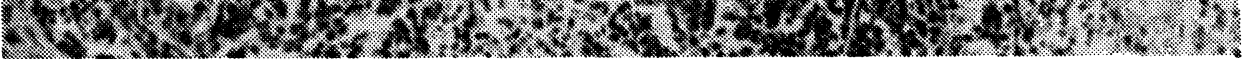

Fig. 5. Bursa of Fabricius, $\mathrm{Si}-1$

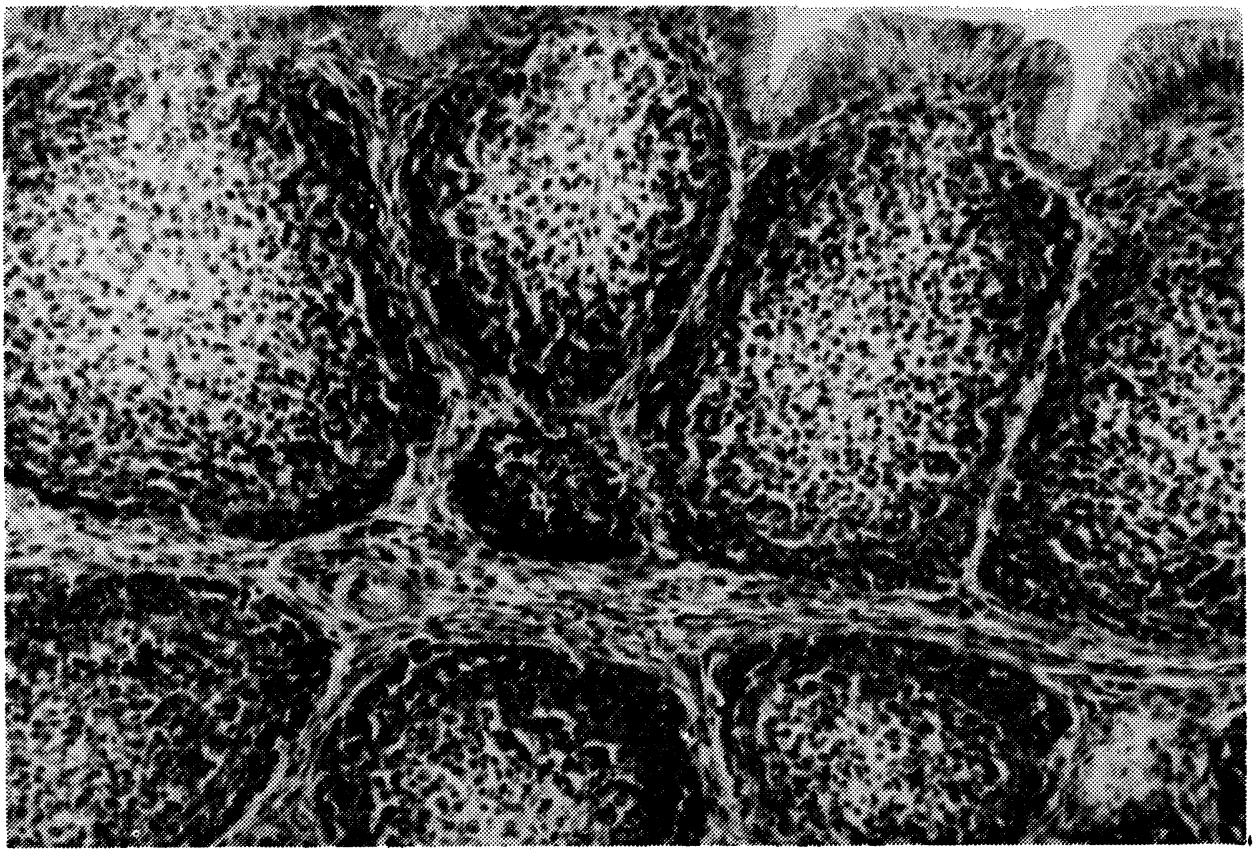

Fig. 6. Bursa of Fabricius, $\mathrm{Si}-2$ 


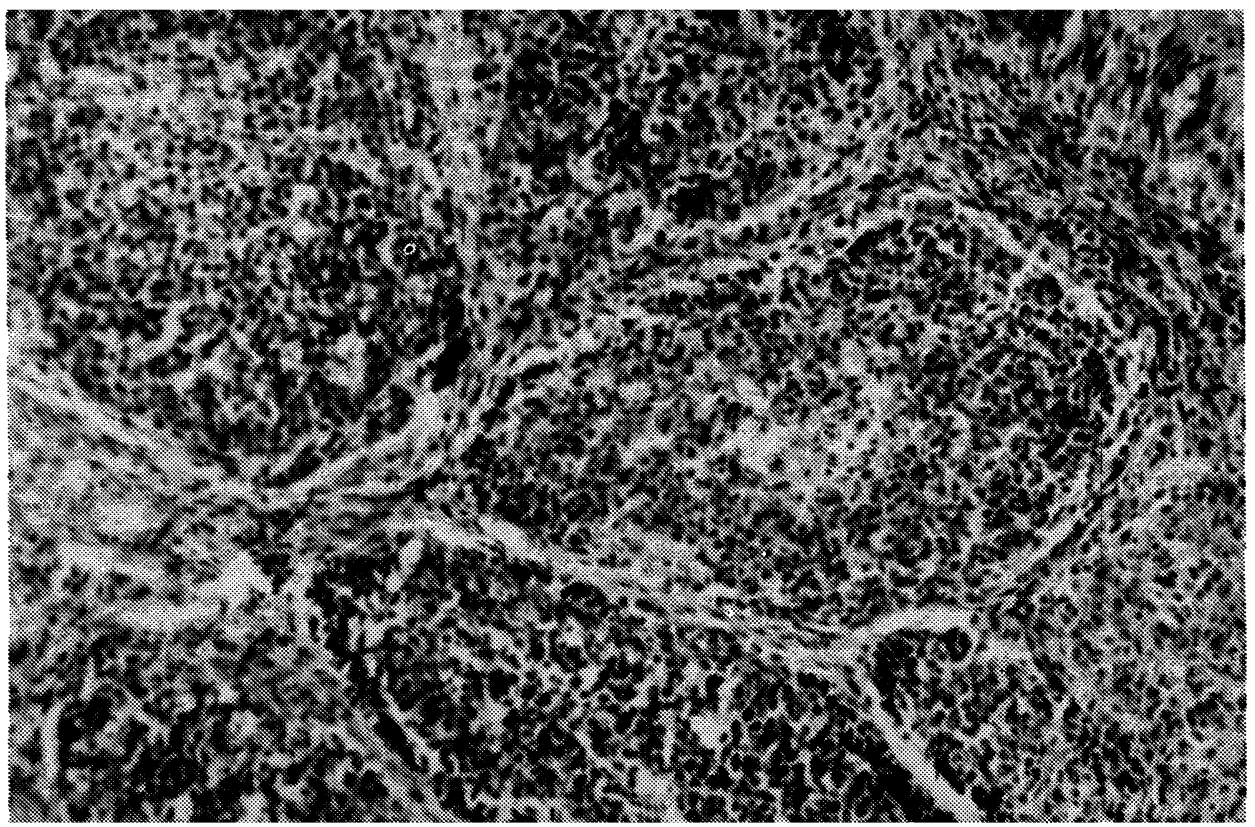

Fig. 7. Bursa of Fabricius, $\mathrm{Si}-3$

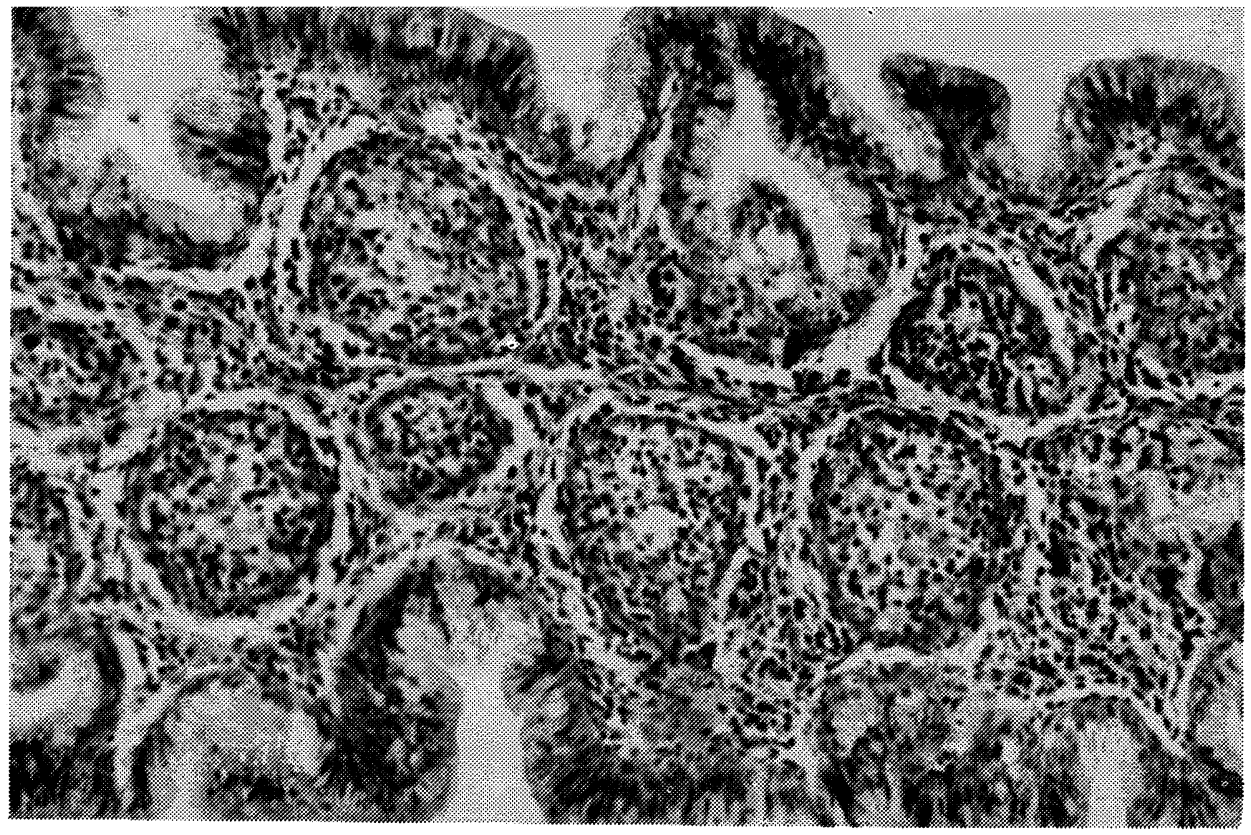

Fig. 8. Bursa of Fabricius, $\mathrm{Si}-4$ 
Plate VII.

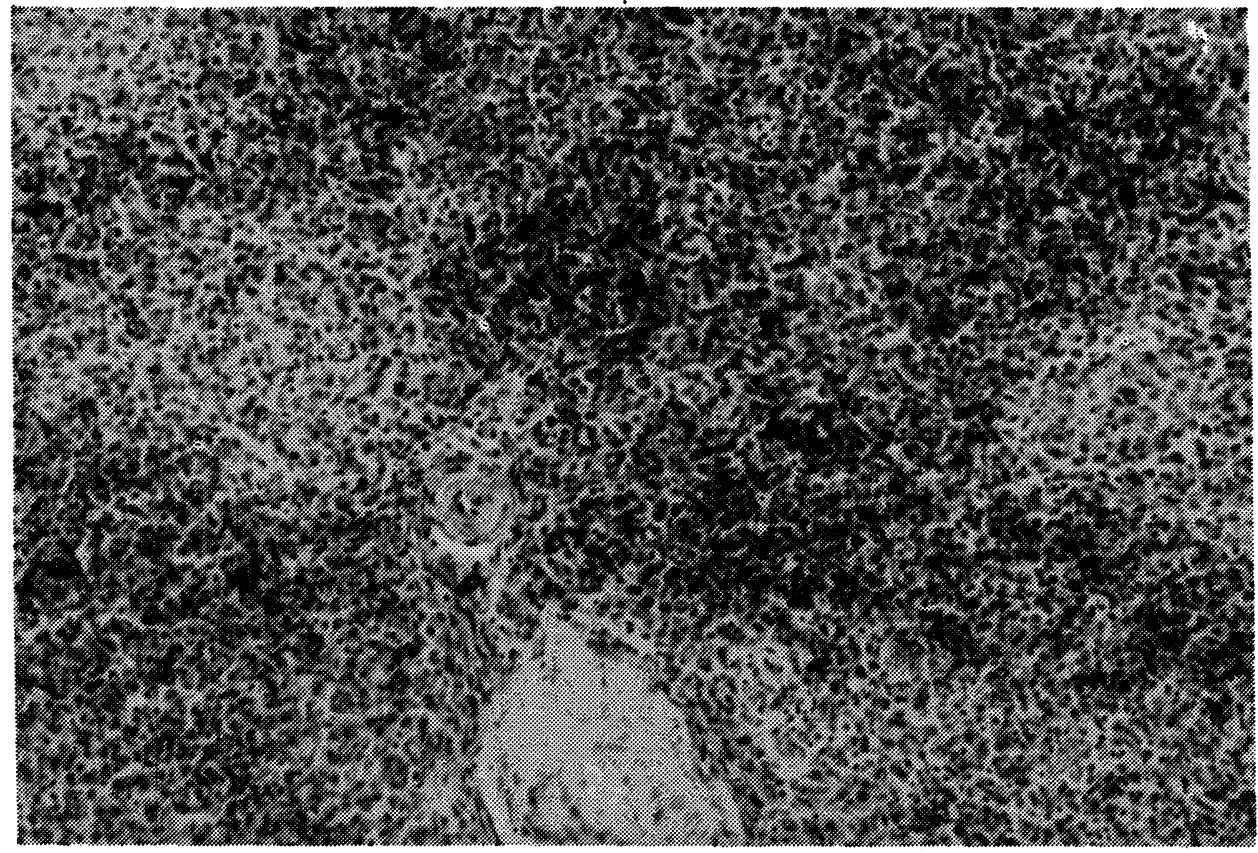

Fig. 9. Spleen, $\mathrm{Si}-1$ (1.)

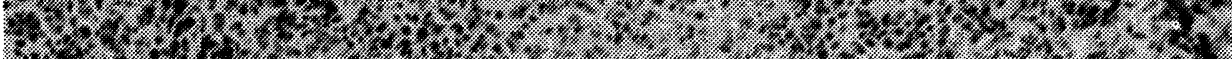
(1. (1) (5.

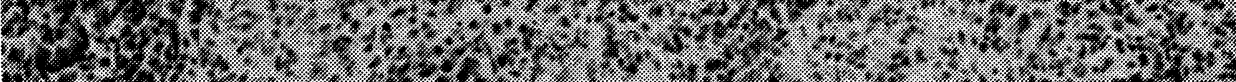
\begin{tabular}{lll}
\hline & -1
\end{tabular} .

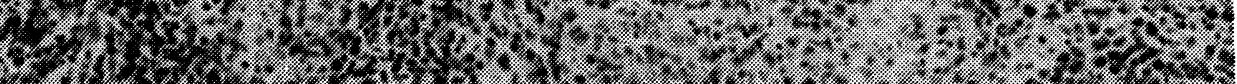

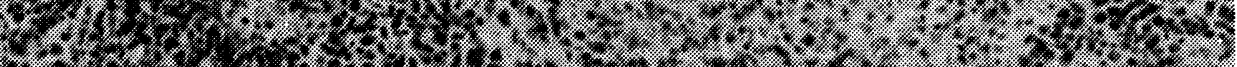

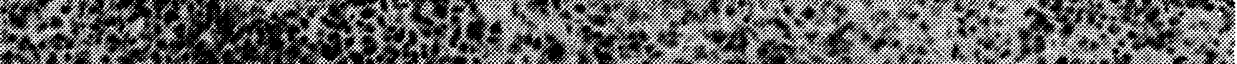

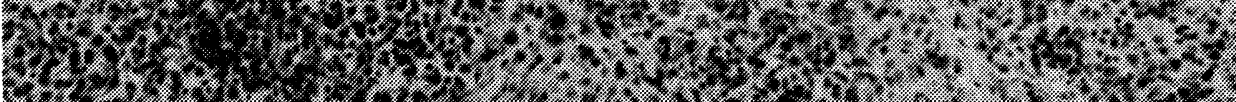

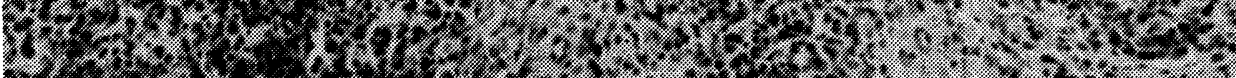

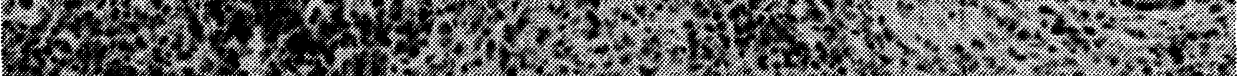
.

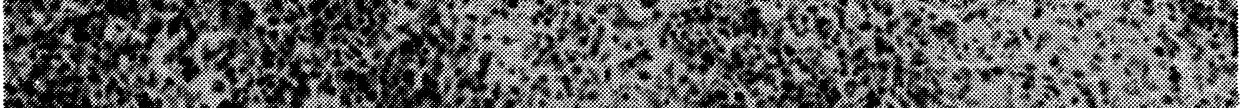
20. 


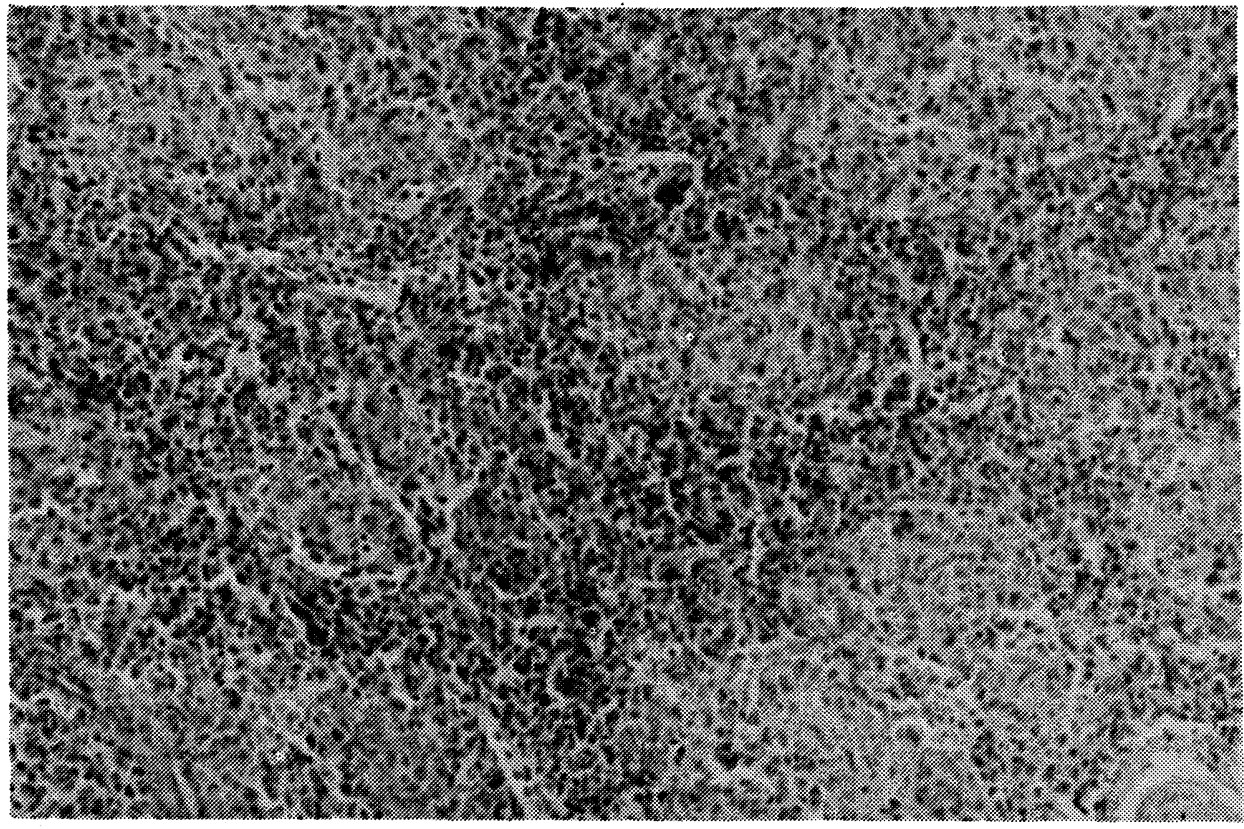

Fig. 11. Spleen, $\mathrm{Si}-3$

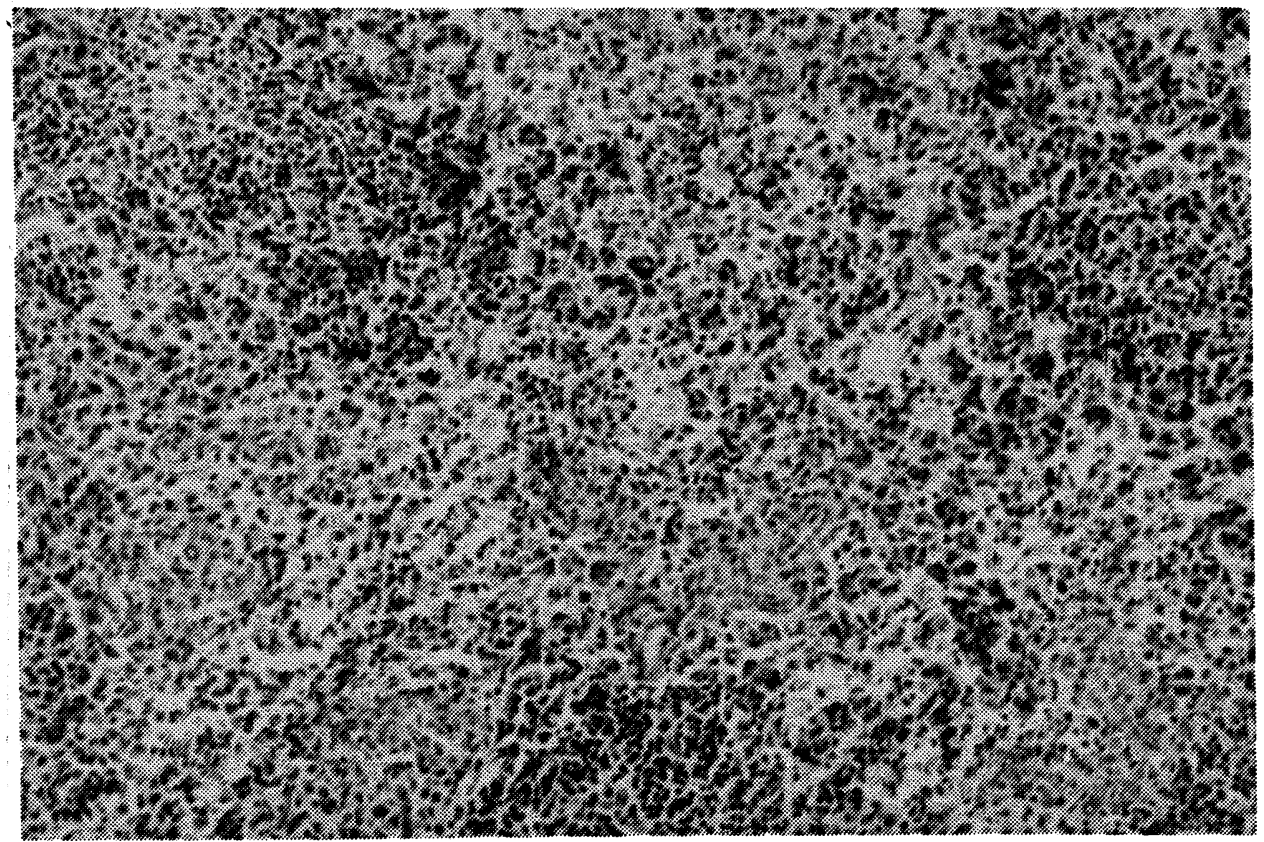

Fig. 12. Spleen, $\mathrm{Si}-4$ 